\title{
Kualitas dan Aktivitas Antioksidan Seduhan Teh Rambut Jagung (Zea mays) dengan Variasi Lama Pelayuan dan Usia Panen
}

\author{
Quality and Antioxidant Activity of Corn Silk (Zea mays) Tea Brew with Variation of \\ Withering Time and Harvest Maturity
}

\author{
Giovanni Natasha Hartanto ${ }{ }^{*}$, Franciscus Sinung Pranata ${ }^{1}$, Yuliana Reni Swasti ${ }^{1}$ \\ ${ }^{\text {I} P r o g r a m ~ S t u d i ~ B i o l o g i, ~ F a k u l t a s ~ T e k n o b i o l o g i, ~ U n i v e r s i t a s ~ A t m a ~ J a y a ~ Y o g y a k a r t a, ~ Y o g y a k a r t a ~}$ \\ E-mail:v_ntsh@yahoo.co.id *Penulis Korespondensi
}

\begin{abstract}
The aim of this research is to find out the influence of the corn silk's harvest maturity against the quality and antioxidant activity of corn silk tea, and the second aim is to find out the best withering time for corn silk tea. The lack of corn silk utilization is potential to process it into a modern yet simple product, i.e. corn silk tea bags. This research used Completely Randomized Design (CRD) factorial $2 \times 3$ with the withering time factors $(0 ; 9 ; 18$ hours) and the harvest maturity factors (immature, harvested 70-80 days after planting; and mature, harvested $>110$ days after planting). The immature corn silk tea which withered for 9 hours exhibited the best quality with $4.48 \%$ of water content, $5.31 \%$ of ash content, $13.66 \%$ of crude fiber content, 19.83 $\mu \mathrm{g} / \mathrm{g}(40 \mathrm{ppm})$ of total phenolic content, DPPH inhibition values of $44.56 \%, 0$ colony/g of Yeast and Molds Test, $1.053 \times 10^{3}$ colony/g of Total Plate Count (TPC) which fit the SNI 3836:2013 standard and favored by panelists
\end{abstract}

Keywords: antioxidant, withering time, corn silk, harvest maturity

\begin{abstract}
Abstrak
Penelitian ini dilakukan untuk mengetahui pengaruh usia panen rambut jagung dan variasi waktu pelayuan terhadap kualitas dan aktivitas antioksidan pada teh rambut jagung. Pemanfaatan rambut jagung masih sangat minim, sehingga berpotensi untuk diolah menjadi teh celup. Penelitian ini menggunakan rancangan acak lengkap (RAL) faktorial $2 \times 3$ dengan faktor lama pelayuan $(0 ; 9 ; 18$ jam) dan usia panen (muda, setelah 70 - 80 hari tanam; dan tua, $>110$ hari setelah tanam). Parameter yang diuji meliputi kadar air (\%), kadar abu (\%), kadar serat kasar (\%), angka kapang khamir (koloni/g), angka lempeng total (koloni/g), warna, kandungan total fenolik dan aktivitas antioksidan. Teh rambut jagung usia panen muda yang dilayukan 9 jam memiliki kualitas yang paling baik dengan dengan kadar air 4,48\%, kadar abu $5,31 \%$, kadar serat kasar $13,66 \%$, total fenolik $19,83 \mu \mathrm{g} / \mathrm{g}(40 \mathrm{ppm})$, aktivitas antioksidan 44,56\%, AKK 0 koloni/g, ALT 1,053 x 10 ${ }^{3}$ koloni/g yang memenuhi SNI 3836:2013 serta disukai panelis.
\end{abstract}

Kata kunci: antioksidan, lama pelayuan, rambut jagung, usia panen

Diterima: 10 Januari 2018, disetujui: 2 Februari 2018

\section{Pendahuluan}

Teh adalah minuman yang dibuat melalui pelayuan, penggilingan dan pengeringan, sehingga menghasilkan rasa dan aroma yang khas. Pelayuan merupakan tahap paling penting karena terjadi proses oksidasi enzimatis yang membentuk citarasa, aroma dan warna khas teh Menurut Kustamiyati (2006), selama pelayuan terjadi penurunan kadar air, protein, pati, gum serta peningkatan kadar gula dan asam amino. Pelayuan sebaiknya dilakukan selama 14-18 jam untuk menghasilkan teh dengan kualitas organoleptik baik. Akan tetapi, waktu pelayuan terlalu lama mengakibatkan proses produksinya tidak efektif, sehingga dilakukan variasi lama pelayuan untuk mengetahui waktu pelayuan paling tepat yang menghasilkan teh rambut jagung dengan kualitas organoleptik yang baik. 
Umumnya, teh dibuat dari pucuk daun teh (Camellia sinensis), tetapi teh dapat dibuat dari bahan lain, salah satunya rambut jagung (Zea mays). Rambut jagung merupakan bagian jagung yang jarang dimanfaatkan, sehingga limbahnya menumpuk seiring dengan peningkatan permintaan konsumen. Padahal rambut jagung memiliki kandungan antioksidan tinggi, terutama polifenol seperti asam ferulat, asam klorogenat, asam kafeat, apigenin dan pelargonidin (Aires dan Carvalho, 2016). Antioksidan dari bahan alam mampu menetralkan radikal dengan memberikan satu elektron pada radikal menjadi non radikal, sehingga penting untuk mencegah kerusakan sel tubuh akibat radikal bebas (Rohmatussolihat, 2009). Akan tetapi, usia panen suatu bahan alam memengaruhi kandungan dan aktivitas antioksidannya, sehingga perlu dilakukan variasi usia panen untuk mengetahui pada tahap usia mana rambut jagung mengandung antioksidan tertinggi setelah diolah menjadi teh.

Teh yang boleh beredar di Indonesia hanyalah teh yang sesuai dengan standar yang ditentukan Badan Standardisasi Nasional, yakni Standar Nasional Indonesia (SNI). Oleh karena itu, pada penelitian ini dilakukan perbandingan hasil uji teh rambut jagung dengan SNI teh kering dalam kemasan (SNI 3836:2013). Kriteria uji yang digunakan meliputi, kadar air, abu total, serat kasar, ALT dan AKK. Hal ini dilakukan untuk menentukan apakah produk teh layak dipasarkan (aman dikonsumsi) dan layak dikembangkan di kemudian hari.

\section{Metode Penelitian}

\section{Bahan}

Bahan yang digunakan berupa rambut jagung manis hibrida varietas Bisi 2 usia panen muda (dipanen 75 hari setelah tanam) dan usia panen tua (dipanen 115 hari setelah tanam) dari perkebunan jagung Sentolo, Kulon Progo, akuades steril, alkohol $70 \%, \mathrm{H}_{2} \mathrm{SO}_{4} 1,25 \%$, $\mathrm{NaOH} 3,25 \%$, reagen Folin-ciocalteu, $\mathrm{Na}_{2} \mathrm{CO}_{3}$ $2 \%$, asam galat, asam askorbat, DPPH 0,2 mM, metanol, medium plate count agar (PCA) dan medium potato dextrose agar (PDA).

\begin{abstract}
Alat
Alat yang digunakan spektrofotometer Genesis 10 UV-Vis, Laminar Air Flow (LAF) ESCO, inkubator Memmert, autoklaf Hirayama HiClave HVE-50, color reader Konika Minolta tipe CR-10, tanur Furnace 1400, vortex dan moisture balancing Melttler Toledo HB 43.
\end{abstract}

\section{Waktu dan Tempat Pelaksanaan Penelitian}

Penelitian ini dilaksanakan pada bulan Oktober 2017 - Desember 2017 di Laboratorium Teknobio-Pangan dan Produksi Fakultas Teknobiologi Universitas Atma Jaya Yogyakarta.

\section{Rancangan Percobaan}

Rancangan percobaan yang digunakan adalah racangan acak lengkap (RAL) faktorial pola 2 × 3 menggunakan 2 faktor perbedaan, yakni faktor perbedaan lama pelayuan $(0,9$ dan 18 jam) dan faktor perbedaan usia panen rambut jagung (usia panen muda dan tua) dengan pengulangan sebanyak 3 kali masing-masing perlakuan.

\section{Cara Kerja}

\section{Penentuan antioksidan dan aktivitas antioksidan bahan awal}

\section{Kadar air (Sudarmadji dkk., 2003)}

Moisture balancing dinyalakan, lalu cawan logam diletakkan, tombol zero ditekan dan ditunggu hingga muncul 0,000 g pada layar. Sampel diletakkan pada cawan hingga mencapai $\pm 1 \mathrm{~g}$, lalu diratakan. Tombol start ditekan, lalu ditunggu hingga pengukuran berhenti dan kadar air yang tertera dicatat.

\section{Preparasi ekstrak rambut jagung (Carbrera dkk., 2015) dengan modifikasi}

Sampel rambut jagung usia muda dan tua masing-masing dihaluskan dengan lumpang porselin. Sampel halus masingmasing diambil $2 \mathrm{~g}$ berat kering, lalu diseduh dalam $200 \mathrm{~mL}$ air suhu $100{ }^{\circ} \mathrm{C}$ selama 5 menit. Larutan disaring, lalu filtrat diuji kandungan antioksidannya. 
Pembuatan kurva standar (Barku dkk., 2013; Orak, 2006) dengan modifikasi

Sebanyak $10 \mathrm{mg}$ asam galat ditimbang dalam labu ukur, kemudian ditambahkan akuades hingga $100 \mathrm{~mL}$, sehingga diperoleh konsentrasi 100 ppm (larutan stock). Larutan stock dihomogenkan, lalu dibuat 2 kurva standar berbeda yang terdiri atas 5 seri konsentrasi, yakni 0, 2, 4, 6, 8, 10 ppm; dan 10, 20, 30, 40, 50 ppm $(\mathrm{mg} / \mathrm{kg})$. Sebanyak $1 \mathrm{~mL}$ larutan dari tiap seri dicampur dengan $5 \mathrm{~mL}$ Folin-ciocalteu (1 : 10) dalam labu ukur, lalu larutan dihomogenkan dan didiamkan 8 menit. Larutan ditambahkan dengan $4 \quad \mathrm{~mL} \quad \mathrm{Na}_{2} \mathrm{CO}_{3} \quad 7,5 \quad \% \quad(\mathrm{~b} / \mathrm{v})$, lalu dihomogenkan dan didiamkan di suhu kamar (27 $\left.{ }^{\circ} \mathrm{C}\right)$ selama 60 menit. Absorbansi diukur menggunakan spektrofotometer $(\lambda=765 \mathrm{~nm})$ dengan persamaan garis linier:

$$
\begin{aligned}
& \mathrm{Y}=(\mathrm{a} \times x)+\mathrm{b} \\
& \text { Keterangan: } \\
& \mathrm{Y}=\text { variabel terikat } \\
& \mathrm{X}=\text { variabel bebas } \\
& \mathrm{A}=\text { intersep } \\
& \mathrm{B}=\text { koefisien regresi }
\end{aligned}
$$

Kandungan total fenolik (Folin-ciocalteu) (Barku dkk., 2013; Orak, 2006) dengan modifikasi

Folin-ciocalteu dilarutkan dalam air 1 : 10, kemudian $1 \mathrm{~mL}$ ekstrak rambut jagung dicampur dengan $5 \mathrm{~mL}$ Folin-ciocalteu, lalu diinkubasi 8 menit dan ditambahkan $4 \mathrm{~mL}$ $\mathrm{Na}_{2} \mathrm{CO}_{3} \quad 7,5 \%$. Campuran ini didiamkan 30 menit pada suhu ruang $\left( \pm 20^{\circ} \mathrm{C}\right)$, lalu absorbansi diukur dengan spektrofotometer $(\lambda=765 \mathrm{~nm})$. Larutan blanko mengandung semua reagen dan pelarut kecuali sampel. Hasil ditentukan dengan kurva standar dan dinyatakan dalam gallic acid equivalent $(\mathrm{GAE}) / \mathrm{mL}$.

\section{Aktivitas antioksidan (Liu dkk., 2011)}

Sebanyak $1 \mathrm{~mL}$ ekstrak rambut jagung ditambah $4 \mathrm{~mL}$ 0,2 mM DPPH (dilarutkan metanol). Larutan dibiarkan 30 menit dalam kondisi gelap hingga berwarna kuning. Larutan blanko yang digunakan terdiri atas semua reagen kecuali ekstrak rambut jagung. Absorbansi larutan diukur menggunakan spektrofotometer $(\lambda=517 \mathrm{~nm})$. Persentase aktivitas penghambatan radikal DPPH (\%) dihitung dengan rumus:
$\% \mathrm{DPPH}=\left(1-\frac{\text { Absorbansi sampel }}{\text { Absorbansi kontrol }}\right) \times 100$

Pembuatan teh rambut jagung (Putri, 2016; Harun dkk., 2011; Balittri, 2012; Handayani, 2010) dengan modifikasi

Rambut jagung usia muda dan tua disortasi untuk mendapatkan warna seragam, lalu dipisahkan dari kotoran. Rambut jagung usia muda dan tua dilayukan secara terpisah pada suhu kamar $\left(27^{\circ} \mathrm{C}\right)$ dalam kondisi tidak terkena sinar matahari secara langsung (ruang beratap) selama 0, 9 dan 18 jam. Rambut jagung dirajang, lalu dikeringkan dalam oven selama 4 jam suhu $55^{\circ} \mathrm{C}$.

Rambut jagung disortasi (layu sempurna dan bebas kotoran), lalu dihaluskan dalam blender kering agar mudah larut saat diseduh. Rambut jagung diayak, kemudian dikemas sebanyak 2 gram berat kering dalam kantung teh agar mudah dilalui air saat penyeduhan. Kantung teh dilekatkan bersama-sama dengan benang teh celup.

Analisis kualitas teh rambut jagung sebelum seduhan

Kadar air (Sudarmadji dkk., 2003)

Cara pengujian kadar air sesuai pada nomor 1a halaman 2 .

\section{Kadar abu (Sudarmadji dkk., 2003)}

Cawan porselin dipanaskan 1 jam, lalu dieksikator dan ditimbang hingga berat konstan. $1 \mathrm{~g}$ sampel dimasukkan ke cawan, lalu dimasukkan ke tanur bersuhu $500{ }^{\circ} \mathrm{C}$ selama 6 jam (pengabuan) hingga sampel berubah menjadi abu keputihan. Sampel kemudian dieksikator selama 15 menit dan ditimbang hingga beratn konstan, lalu kadar abu dihitung dengan rumus:

$$
\text { Kadar abu }=\frac{[\text { [b.cawan+abu }]-b . c a w a n]}{b . a w a l ~ s a m p e l ~(G)} \times 100
$$

Kadar serat kasar (Badan Standardisasi Nasional, 1992)

Kertas saring dioven selama 1 jam suhu 105-110 ${ }^{\circ} \mathrm{C}$, kemudian dieksikator selama 10 menit dan beratnya diukur (A). 0,5 g sampel dimasukkan dalam erlenmeyer $250 \mathrm{~mL}$, lalu ditambahkan $200 \quad \mathrm{~mL} \quad \mathrm{H}_{2} \mathrm{SO}_{4} \quad 1,25 \quad \%$ dan didihkan selama 30 menit. Sampel disaring 
dengan kertas saring, lalu residu dibilas akuades panas dan dicuci $200 \mathrm{~mL} \mathrm{NaOH} \mathrm{3,25 \% .}$

Residu ditampung pada erlenmeyer, kemudian dididihkan 30 menit dan hasil pencucian disaring kembali. Residu yang tersaring dibilas dengan akuades panas, lalu residu pada kertas saring dikeringkan pada oven selama 5-8 jam suhu 105-110 ${ }^{\circ} \mathrm{C}$. Residu dieksikator 10 menit, lalu beratnya ditimbang (B). Kadar serat dihitung dengan rumus:

$$
\text { Serat kasar }=\frac{\mathrm{B}-\mathrm{A}}{\text { bawalsampel }(\mathrm{g})} \times 100 \%
$$

\section{Angka Kapang/Khamir (AKK) (Fardiaz dan Margiono, 1993)}

Sebanyak 1 g sampel dilarutkan dalam 9 $\mathrm{mL}$ akuades steril 9, lalu dihomogenkan sampai rata dan diberi label $10^{-1}$. Pengenceran $10^{-1}$ diambil $1 \mathrm{~mL}$, kemudian dicampur dengan $9 \mathrm{~mL}$ akuades dalam tabung reaksi yang diberi label $10^{-2}$. Pengenceran $10^{-2}$ diambil $1 \mathrm{~mL}$, kemudian dicampur dengan $9 \mathrm{~mL}$ akuades dalam tabung reaksi yang diberi label $10^{-3}$. Pengenceran dilanjutkan hingga $10^{-5}$, kemudian masingmasing diinokulasikan $1 \mathrm{~mL}$ ke medium potato dextrose agar (PDA) padat pada cawan petri dengan metode spread plate. Medium diinkubasi pada suhu $37{ }^{\circ} \mathrm{C}$ selama 48 jam, kemudian koloni yang terbentuk dihitung.

Penyeduhan teh rambut jagung (Dewi, 2016) dengan modifikasi

Produk teh celup rambut jagung ( $2 \mathrm{~g}$ ) direndam dalam air $100{ }^{\circ} \mathrm{C}$ selama 5 menit hingga terjadi perubahan warna kekuningan.

Analisis kualitas teh rambut jagung setelah seduhan

\section{Warna teh rambut jagung (deMan, 1977)}

Seduhan teh rambut jagung dimasukkan ke plastik bening, lalu color reader dinyalakan dan sistem L, a, b dipilih. Ujung reseptor color reader ditempelkan pada sampel dan tombol pengukuran ditekan, hal ini diulang 3 kali di tempat berbeda. Nilai L, a, b yang diperoleh dicatat, kemudian nilai $\mathrm{x}$ dan y diplotkan pada diagram kromatografi CIE untuk memperoleh zona warna sampel. Nilai $\mathrm{x}$ dan $\mathrm{y}$ dihitung menggunakan rumus:

$$
\begin{aligned}
& \mathrm{X}= \frac{\overline{\mathrm{a}}+1_{x} 75 \times \overline{\mathrm{L}}}{(5,645 \times \overline{\mathrm{L}})+\overline{\mathrm{a}}-(3,012 \times \overline{\mathrm{b}})} \\
& \mathrm{Y}=\frac{1_{x} 786 \times \overline{\mathrm{L}}}{(5,645 \times \overline{\mathrm{L}})+\overline{\mathrm{a}}-(3,012 \times \overline{\mathrm{b}})} \\
& \\
& \text { Keterangan: } \\
& \mathrm{L}=\text { lightness } \text { (kecerahan) } \\
& \mathrm{a}=\text { kemerahan dan kehijauan } \\
& \mathrm{b}=\text { kekuningan dan kebiruan }
\end{aligned}
$$

\section{Analisis Angka Lempeng Tota (Fardiaz dan Margiono, 1993)}

Sampel diambil $1 \mathrm{~g}$ dan dilarutkan dalam $9 \mathrm{~mL}$ akuades steril 9, lalu dihomogenkan sampai rata dan diberi label $10^{-1}$. Pengenceran $10^{-1}$ diambil $1 \mathrm{~mL}$, kemudian dicampur dengan 9 $\mathrm{mL}$ akuades dalam tabung reaksi yang diberi label $10^{-2}$. Pengenceran $10^{-2}$ diambil $1 \mathrm{~mL}$, kemudian dicampur dengan $9 \mathrm{~mL}$ akuades dalam tabung reaksi yang diberi label $10^{-3}$. Pengenceran dilanjutkan hingga $10^{-5}$, kemudian masingmasing pengenceran diambil sebanyak $1 \mathrm{~mL}$ dan dimasukkan pada cawan petri kosong. Media plate count agar (PCA) cair dituangkan pada petri berisi sampel (pour plate). Masing-masing petri diinkubasi selama 48 jam dengan suhu 37 ${ }^{\circ} \mathrm{C}$.

\section{Uji organoleptik (Dewi, 2016) dengan modifikasi}

Uji organoleptik ini diikuti oleh 30 orang panelis yang terdiri dari 15 wanita dan 15 pria yang masing-masing diberi 6 cangkir seduhan teh (3 cangkir teh usia muda dilayukan $0,9,18$ jam; 3 cangkir teh usia tua dilayukan $0,9,18$ jam). Parameter yang diuji meliputi warna, aroma dan rasa dengan dalam kisaran skor 1-6, yakni $6=$ sangat amat suka; $5=$ sangat suka; $4=$ suka; 3 = agak suka; $2=$ sedikit suka dan $1=$ tidak suka.

Analisis antioksidan teh rambut jagung (Barku dkk., 2013; Orak, 2006; Liu dkk., 2011) dengan modifikasi

Cara pengujian total fenolik dengan metode Folin-ciocalteu sesuai pada nomor 1d halaman 3 dan uji aktivitas antioksidan (DPPH) sesuai dengan nomor 1e halaman 3 . 


\section{Analisis Data (Gasperz, 1991)}

Analisis data menggunakan ANAVA dan jika diperoleh beda nyata antar perlakuan dilanjutkan uji duncan's multiple range test (DMRT) pada tingkat kepercayaan 95\%.

\section{Hasil dan Pembahasan}

\section{Penentuan Total Fenol dan Aktivitas Antioksidan Bahan Awal}

Penetuan kadar air, total fenol dan aktivitas antioksidan bahan awal dilakukan untuk mengetahui adanya perubahan kadar air maupun antioksidan bahan sebelum dan sesudah diolah menjadi teh celup. Hasil analisis bahan awal dapat dilihat pada Tabel 1.

Kadar air rambut jagung usia muda lebih tinggi dibandingkan usia muda (Tabel 1), sehingga sesuai teori Huang dkk., (2012), bahwa kadar air rambut jagung menurun secara drastis selama masa pertumbuhan tanaman karena dibutuhkan energi yang dalam air untuk fotosintesis dan penyerbukan (Pertamawati, 2010). Total fenolik dan aktivitas antioksidan ekstrak rambut jagung usia muda lebih tinggi dibandingkan usia tua karena pada perkecambahan terjadi katabolisme protein menjadi asam amino (fenil analin), sehingga sintesis fenol dapat berjalan dengan adanya substrat fenil analin, kandungan fenolnya lebih tinggi pada usia muda (waktu panen lebih dekat dengan perkecambahan) (McWilliams, 1999; Lee, 2007; Murdijati dan Yuliana, 2014). Rambut jagung usia muda memiliki aktivitas antioksidan lebih tinggi dibanding usia tua karena aktivitas antioksidan suatu bahan dipengaruhi oleh adanya senyawa fenolik bahan karena fenol memiliki beberapa aktivitas antioksidan.

Analisis Kualitas Teh Rambut Jagung Variasi
Usia Panen dan Lama Pelayuan Sebelum Seduhan

\section{Kadar Air}

Penentuan kadar air produk teh dilakukan untuk menentukan apakah produk teh aman dikonsumsi dengan membandingkan. Selain itu, untuk menentukan daya awet bahan pangan karena air merupakan media tumbuh kapang/khamir dan bakteri. Hasil analisis kadar air dapat dilihat pada Tabel 2 .

Kadar air teh rambut jagung berkisar 4,48\%-6,68\% (Tabel 2), sehingga sesuai SNI 3836:2013, yakni maks. 8\%. Kadar air teh rambut jagung usia muda lebih rendah dibanding usia tua, sehingga tidak sesuai teori Huang dkk., (2012), bahwa rambut jagung usia panen tua memiliki kadar air lebih rendah dibanding usia muda. Hal ini karena laju transpirasi rambut jagung tua yang lebih cepat dibandingkan rambut jagung muda karena bentuk rambut jagung tua lebih tipis, sehingga luas permukaan transpirasi semakin besar dan kemungkinan kehilangan air makin besar (Murdijati dan Yuliana, 2014). Perlakuan lama pelayuan memberikan hasil yang tidak berbeda nyata pada kadar air teh rambut jagung. Hal ini menunjukkan bahwa dalam 0-18 jam pelayuan, penurunan kadar air produk cenderung konstan.

Tabel 1. Kadar air, total fenolik dan aktivitas antioksidan bahan awal rambut jagung

\begin{tabular}{cccc}
\hline \hline \multirow{2}{*}{ Usia panen } & Kadar air & Total Fenolik & Inhibisi DPPH \\
\cline { 2 - 4 } & $(\boldsymbol{\%})$ & $(\boldsymbol{\mu g} / \mathbf{g})$ & $(\boldsymbol{\%})$ \\
\hline \hline Muda & 84,916 & 23,58 & 50 \\
Tua & 6,543 & 19,25 & 42,57 \\
\hline \hline
\end{tabular}

Tabel 2. Kadar air teh rambut jagung

\begin{tabular}{|c|c|c|c|}
\hline Perlakuan & \multirow{2}{*}{\multicolumn{2}{|c|}{$\begin{array}{c}\text { Kadar air }(\%) \\
\text { Usia panen }\end{array}$}} & \multirow{3}{*}{$\overline{\mathbf{x}}$} \\
\hline \multirow{2}{*}{ Lama pelayuan } & & & \\
\hline & Muda & Tua & \\
\hline (0 jam (kontrol) & $4,49^{\mathrm{a}}$ & $6,68^{b}$ & $\overline{75,80^{\mathrm{A}}}$ \\
\hline 9 jam & $4,48^{\mathrm{a}}$ & $5,12^{a}$ & $4,80^{\mathrm{A}}$ \\
\hline $18 \mathrm{jam}$ & $5,05^{\mathrm{a}}$ & $5,16^{\mathrm{a}}$ & $5,59^{\mathrm{A}}$ \\
\hline$\overline{\overline{\mathbf{x}}}$ & $4,48^{X}$ & $5,9^{\mathrm{Y}}$ & \\
\hline
\end{tabular}

*Nilai yang diikuti huruf yang sama menunjukkan perbedaan yang tidak nyata $(\mathrm{P}>0,01)$ 


\section{Kadar Abu}

Pengukuran kadar abu bahan pangan dilakukan untuk mengetahui banyaknya kandungan mineral suatu bahan pangan. Hasil analisis kadar abu dapat dilihat pada Tabel 3.

Kadar abu teh rambut jagung berkisar 3,5\%-5,31\% (Tabel 3), sehingga sesuai SNI 3836:2013, yakni kadar abu total produk teh kering maksimal 8\%. Kadar abu teh rambut jagung usia muda lebih rendah dibanding usia tua karena perbedaan usia panen mempengaruhi kandungan mineral, mineral $\mathrm{Mg}$ memiliki peran penting dalam pertumbuhan tanaman (unsur utama klorofil, mengatur pertukaran fosfat dan pernapasan (Hartiko, 1983; Prihmantoro dan Indriani, 1995). Semakin tua usia tanaman, maka kandungan mineralnya makin berkurang (terutama $\mathrm{Mg}$ ) sehingga kadar abunya menurun. Perlakuan lama pelayuan tidak memberikan beda nyata pada kadar abu, yakni tidak ada perbedaan kadar abu yang signifikan antarperlakuan lama pelayuan karena hasil yang diperoleh stabil.

\section{Kadar Serat Kasar}

Kadar serat teh merupakan parameter penting karena kandungan serat yang terlalu tinggi (> 16,5 \%) menunjukkan pemakaian batang teh yang kotor, sehingga disimpulkan bahwa proses produksi yang dilakukan kurang baik (Venkatesan dan Sujitha, 2007). Hasil analisis kadar serat kasar dapat dilihat pada Tabel 4.

Teh rambut jagung memiliki kadar serat kasar antara 8,43\%-15,52\% (Tabel 4), sehingga sesuai SNI 3836:2013, yakni kadar serat kasar produk teh kering maksimal 16,5\%. Perlakuan usia panen tidak berbeda nyata pada produk teh, sehingga variasi usia panen pada rambut jagung tidak mempengaruhi kadar serat kasar teh. Semakin lama pelayuan dilakukan, semakin tinggi pula kadar serat kasar teh karena semakin lama pelayuan, maka kadar air semakin menurun (Sembiring, 2009), kadar serat pun meningkat karena terjadi pemekatan bahan dalam produk pangan, salah satunya serat kasar (hemiselulosa, selulosa dan lignin).

\section{Jumlah Angka Kapang Khamir (AKK)}

Penentuan AKK penting dilakukan karena kapang dan khamir dapat mendegradasi makromolekul seperti protein menjadi asam amino, lemak menjadi asam lemak dan karbohidrat menjadi monosakarida dalam bahan, sehingga mengurangi nilai gizi bahan (Muchtadi, 1989). Hasil analisis AKK dapat dilihat pada Tabel 5.

Angka kapang/khamir teh rambut jagung berkisar 0-1,67 x 10² koloni/g (Tabel 5), sehingga sesuai SNI 3836:2013, yaitu AKK teh kering maksimal $5 \times 10^{2}$ koloni/g. Perlakuan usia panen rambut jagung tidak beda nyata dan cenderung jumlah AKK-nya rendah produk karena adanya zat antifungi pada rambut jagung berupa minyak atsiri yang mampu menghambat tumbuhnya jamur (Apriady, 2010). Perlakuan lama pelayuan rambut jagung juga tidak beda nyata, yakni jumlah AKK-nya sama karena jumlah kapang/khamir suatu bahan lebih dipengaruhi oleh lama penyimpanan bahan baku dibandingkan perlakuan. Berbeda dengan ALT yang jumlahnya sensitif terhadap kontaminasi dan perlakuan. Hal ini disebabkan pertumbuhan kapang/khamir hanya terjadi pada keadaan khusus, seperti jumlah $\mathrm{A}_{\mathrm{w}}$ yang cukup, $\mathrm{pH}$ yang tepat dan tekanan osmotik tertentu (Rafiqah, 2011).

Analisis Kualitas Seduhan Teh Rambut Jagung Variasi Usia Panen dan Lama Pelayuan

\section{Warna Seduhan}

Warna penting bagi produk pangan, baik makanan yang diproses maupun tidak. Warna bersama dengan aroma, rasa dan tekstur memegang peran penting dalam penerimaan makanan. Warna juga dapat memberi petunjuk perubahan kimia makanan seperti pencokelatan dan pembusukan (deMan, 1999). Warna seduhan teh rambut jagung berdasarkan indera penglihatan dapat dilihat pada Gambar 1 .

Warna cokelat kekuningan pada seduhan teh dipengaruhi oleh reaksi oksidasi enzimatis selama pelayuan, yakni polimerisasi o-quinon dengan polifenol rambut jagung membentuk pigmen cokelat melanoidin (Siegbahn, 2004). Warna seduhan teh rambut jagung semakin memudar, semakin tua usia panen (Gambar 1). Kandungan total fenol pada rambut jagung usia tua rendah (Sarepoua dkk., 2015), sehingga semakin rendah fenol, maka melanoidin yang terbentuk makin rendah dan warnanya memudar. Warna seduhan teh rambut jagung semakin memudar, seiring bertambahnya waktu pelayuan 
(Gambar 1) karena waktu pelayuan terlalu lama, sehingga terjadi oksidasi polifenol secara terus menerus (Siegbahn, 2004), kemudian o-quinon tidak dapat berpolimerisasi dengan fenol dalam pembentukan melanoidin dan mengakibatkan penurunan warna.

Analisis warna seduhan teh rambut jagung melalui color reader dengan metode $\mathrm{L}, \mathrm{a}, \mathrm{b}$ menunjukkan semua perlakuan berada di daerah warna sumber cahaya (putih), kecuali rambut jagung usia muda 0 jam pelayuan, yakni berada di daerah warna merah muda (pink). Hasil analisis warna color reader tidak sesuai dengan warna seduhan (Gambar 1). Hal ini disebabkan latar pengukuran warna yang memengaruhi hasil atau terlalu beningnya seduhan teh, sehingga cahaya yang terekam dalam alat tidak sesuai dengan warna sampel dan hasilnya tidak valid.

Tabel 3. Kadar abu teh rambut jagung

\begin{tabular}{|c|c|c|c|}
\hline Perlakuan & \multicolumn{2}{|c|}{ Kadar abu (\%) } & \multirow{3}{*}{$\overline{\mathbf{x}}$} \\
\hline \multirow{2}{*}{ Lama pelayuan } & \multicolumn{2}{|c|}{ Usia panen } & \\
\hline & Muda & Tua & \\
\hline 0 jam (kontrol) & $5,22^{\mathrm{a}}$ & $3,46^{\mathrm{a}}$ & $4,34^{\mathrm{A}}$ \\
\hline 9 jam & $5,31^{\mathrm{a}}$ & $3,5^{\mathrm{a}}$ & $4,40^{\mathrm{A}}$ \\
\hline $18 \mathrm{jam}$ & $5,12^{\mathrm{a}}$ & $3,5^{\mathrm{a}}$ & $4,31^{\mathrm{A}}$ \\
\hline$\overline{\mathbf{x}}$ & $5,21^{X}$ & $3,48^{\mathrm{Y}}$ & \\
\hline
\end{tabular}

*Nilai yang diikuti huruf yang sama menunjukkan perbedaan yang tidak nyata $(\mathrm{P}>0,01)$

Tabel 4. Serat kasar teh rambut jagung

\begin{tabular}{|c|c|c|c|}
\hline Perlakuan & \multicolumn{2}{|c|}{ Serat kasar (\%) } & \multirow{3}{*}{$\overline{\mathbf{x}}$} \\
\hline \multirow{2}{*}{ Lama pelayuan } & \multicolumn{2}{|c|}{ Usia panen } & \\
\hline & Muda & Tua & \\
\hline 0 jam (kontrol) & $10,16^{\mathrm{a}}$ & $8,43^{\mathrm{a}}$ & $9,29^{\mathrm{A}}$ \\
\hline 9 jam & $13,66^{\mathrm{b}}$ & $9,89^{\mathrm{a}}$ & $11,77^{\mathrm{B}}$ \\
\hline $18 \mathrm{jam}$ & $14,26^{\mathrm{b}}$ & $15,52^{\mathrm{b}}$ & $14,89^{\mathrm{C}}$ \\
\hline$\overline{\mathbf{x}}$ & $12,69^{x}$ & $11,28^{x}$ & \\
\hline
\end{tabular}

*Nilai yang diikuti huruf yang sama menunjukkan perbedaan yang tidak nyata $(\mathrm{P}>0,01)$

Tabel 5. Angka kapang/khamir teh rambut jagung

\begin{tabular}{|c|c|c|c|}
\hline Perla-kuan & \multicolumn{2}{|r|}{ AKK (koloni/g) } & \multirow{3}{*}{$\overline{\mathbf{x}}$} \\
\hline \multirow{2}{*}{ Lama pela-yuan } & \multicolumn{2}{|r|}{ Usia panen } & \\
\hline & Mu-da & Tua & \\
\hline 0 jam & $0^{\mathrm{a}}$ & $1,67 \times 10^{2 \mathrm{a}}$ & $0,83 \times 10^{2 \mathrm{~A}}$ \\
\hline 9 jam & $0^{\mathrm{a}}$ & $1,67 \times 10^{2 \mathrm{a}}$ & $0,83 \times 10^{2 \mathrm{~A}}$ \\
\hline $18 \mathrm{jam}$ & $0^{\mathrm{a}}$ & $1,67 \times 10^{2 \mathrm{a}}$ & $0,83 \times 10^{2 \mathrm{~A}}$ \\
\hline$\overline{\mathbf{x}}$ & $0^{\mathrm{X}}$ & $1,67 \times 10^{2 \times}$ & \\
\hline
\end{tabular}

*Nilai yang diikuti huruf yang sama menunjukkan perbedaan yang tidak nyata $(\mathrm{P}>0,01)$

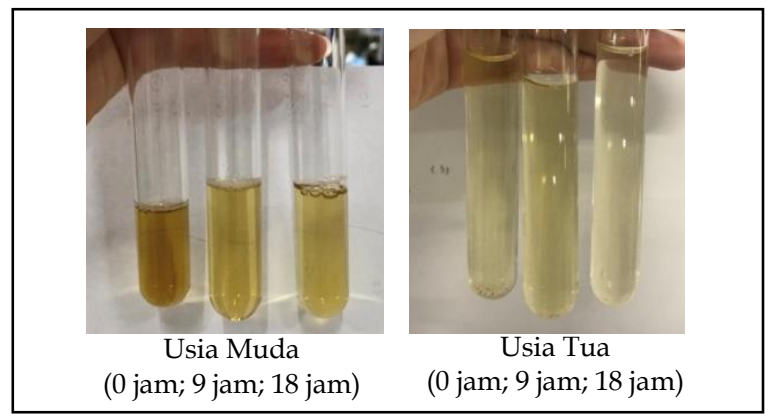

Gambar 1. Warna seduhan teh rambut jagung variasi lama pelayuan dan usia panen. 


\section{Jumlah Angka Lempeng Total (ALT)}

Uji ALT berpengaruh penting untuk mengetahui kualitas suatu bahan pangan karena mampu menduga daya tahan simpan makanan, sebagai indikator sanitasi atau keamanan makanan (Fardiaz, 1992). Hasil analisis kadar serat kasar dapat dilihat pada Gambar 2.

ALT teh rambut jagung berkisar antara $0,498 \times 10^{3}-1,053 \times 10^{3} \mathrm{koloni} / \mathrm{g}$, sehingga sesuai SNI 3836:2013, yaitu ALT produk teh kering maks. $3 \times 10^{3}$ koloni/g. Perlakuan usia panen memberikan hasil tidak beda nyata karena dilakukan penyeduhan teh dengan suhu seragam $\left(100{ }^{\circ} \mathrm{C}\right)$, sehingga bakteri aerob mesofil yang hanya mampu bertahan pada suhu $25-37^{\circ} \mathrm{C}$ mengalami kematian dan jumlah ALT-nya cukup rendah dan seragam antarperlakuan (Hidayat, 2006). Gambar 2 menunjukkan semakin lama waktu pelayuan, maka semakin meningkat ALT. ALT tertinggi pada pelayuan 18 jam karena waktu pelayuan lama, sehingga kemungkinan rambut jagung terpapar bakteri udara lebih tinggi, sedangkan ALT paling rendah pada pelayuan 0 jam karena tidak dilakukan pelayuan, dimana rambut jagung langsung dioven, sehingga kemungkinan terpapar bakteri udara lebih kecil.

\section{Organoleptik}

Tujuan uji organoleptik adalah untuk mengetahui tingkat kesukaan dan penerimaan panelis terhadap produk makanan/minuman. Hasil uji organoleptik terhadap warna, rasa dan aroma produk teh rambut jagung dapat dilihat pada Gambar 3.

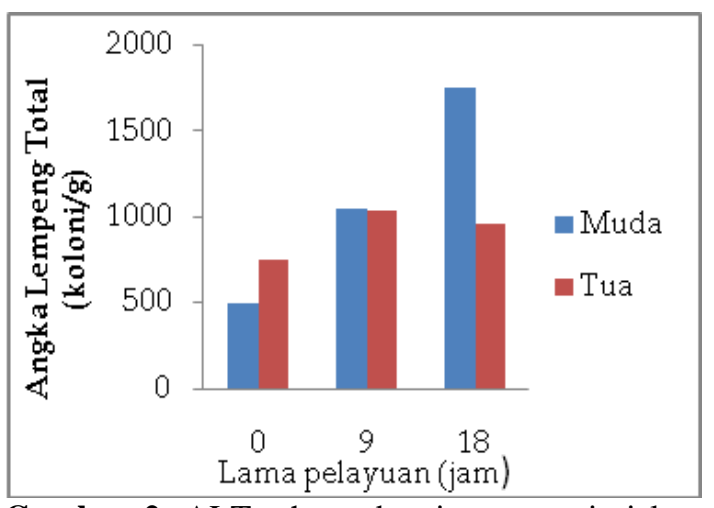

Gambar 2. ALT teh rambut jagung variasi lama pelayuan dan usia panen

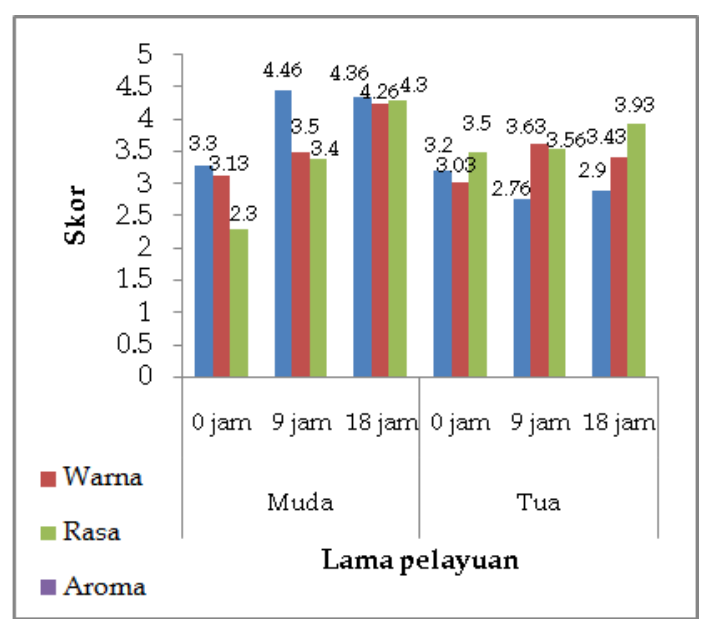

Gambar 3. Organoleptik teh rambut jagung variasi lama pelayuan dan usia panen.

Keterangan: (1) tidak suka; (2) sedikit suka; (3) agak suka; (4) suka; (5) sangat suka; (6) amat sangat suka 
Pada parameter warna diketahui bahwa warna seduhan teh usia panen muda lebih menarik dari usia tua (kuning kecokelatan), karena rendahnya total fenolik pada rambut jagung usia panen tua (Sarepoua dkk., 2015), sehingga pigmen warna melanoidin yang dihasilkan selama polimerisasi dengan o-quinon rendah juga. Semakin lama pelayuan, maka warnanya makin menarik karena selama pelayuan terjadi oksidasi enzimatis yang memecah senyawa fenol menjadi melanoidin yang memberi warna seduhan teh (Taranto dkk., 2017).

Parameter rasa menunjukkan semakin muda usia panen, maka rasa semakin disukai karena jagung muda memiliki tanin tinggi (398 $\mathrm{mg} / 100 \mathrm{mg}$ ) (Santosh, 2005) yang memberi citarasa sepat khas teh. Semakin lama pelayuan, semakin disukai rasanya karena selama pelayuan 14-18 jam, terjadi aktivasi enzim polifenol oksidase, citarasa teh terbentuk dari pemecahan protein menjadi asam amino (Arifin, 1994; Kustamiyati, 2006).

Pada parameter aroma, semakin muda usia panen, aromanya makin sedap karena senyawa volatil pada daun muda lebih tinggi dibandingkan daun tua pada beberapa kultivar (Azam dkk., 2013). Semakin lama pelayuan, aroma semakin sedap karena rambut jagung mengandung senyawa volatil, yakni 99\% terpenoid (El-Ghorab dkk., 2007). Selama pelayuan muncul senyawa terpenoid baru melalui reaksi sekunder (oksidasi), sehingga bertambahnya senyawa terpenoid akan meningkatkan aroma. Secara keseluruhan, teh yang paling disukai adalah teh rambut jagung usia muda 18 jam pelayuan, sedangkan yang paling tidak disukai adalah teh rambut jagung usia muda 0 jam pelayuan.

\section{Kandungan total fenolik}

Penentuan kandungan total fenolik untuk mengetahui kandungan antioksidan produk teh yang diproses melalui perlakuan berbeda, sehingga diketahui pengaruh perbedaan usia panen dan lama pelayuan pada kadar antioksidan produk. Hasil analisis kandungan total fenolik dapat dilihat pada Tabel 6.

Semakin tua usia panen, maka kandungan fenoliknya makin rendah (Tabel 6) karena pada perkecambahan terjadi proses katabolisme protein menjadi asam amino (fenil analin), sehingga sintesis fenol dapat berjalan dengan adanya substrat berupa fenil analin (McWilliams, 1999; Lee, 2007 dan Murdijati dan Yuliana, 2014). Kandungan fenolik rambut jagung usia tua yang rendah karena respirasi tanaman selama penuaan, sehingga asam-asam organik (senyawa fenolat) yang merupakan cadangan energi menurun (Santoso dkk., 2012). Semakin lama pelayuan, maka semakin rendah kandungan fenoliknya karena adanya oksidasi enzimatis selama pelayuan, sehingga senyawa fenol teroksidasi dan jumlahnya menurun (Sukalovic dkk., 2009).

\section{Aktivitas antioksidan (persentase inhibisi radikal DPPH)}

Penentuan aktivitas antioksidan dilakukan untuk mengetahui seberapa besar aktivitas antioksidan pada produk untuk mencegah/ menginhibisi adanya radikal bebas berupa DPPH. Hasil analisis aktivitas antioksidan dapat dilihat pada Tabel 7.

Semakin tua usia panen, semakin rendah aktivitas antioksidan seduhan teh rambut jagung karena respirasi tanaman selama penuaan, sehingga asam-asam organik (senyawa fenolat) yang merupakan cadangan energi menurun (Santoso dkk., 2012). Lama pelayuan memberikan hasil beda nyata pada 18 jam pelayuan terjadi pencokelatan yang disebabkan oleh polifenol oksidase, sehingga terjadi oksidasi komponen fenolik (Murdijati dan Yuliana, 2014) dan aktivitas antioksidan produk menurun, sehingga kemampuan dalam menghambat radikal DPPH rendah.

Hasil penelitian total fenolik dan aktivitas antioksidan menunjukkan hasil yang sama, yakni usia muda memiliki kandungan total fenolik dan aktivitas antioksidan yang lebih tinggi, sehingga sesuai dengan Sarepoua dkk., (2015), bahwa semakin muda usia panen rambut jagung, maka kandungan dan aktivitas antioksidannya semakin tinggi. Aktivitas antioksidan suatu bahan dipengaruhi oleh adanya senyawa fenolik, sehingga hasil total fenolik seharusnya berbanding lurus (berkorelasi positif) dengan hasil aktivitas antioksidan karena jumlah fenolik tinggi menandakan aktivitas antioksidan tinggi karena fenolik mampu menghambat radikal 
bebas DPPH dengan menyumbangkan atom $\mathrm{H}$, sehingga radikal menjadi lebih stabil.

Secara keseluruhan, produk teh rambut jagung terbaik adalah produk teh rambut jagung usia panen muda yang dilayukan selama 9 jam dengan rerata organoleptik tinggi $(3,78)$; total fenolik tinggi $19,83 \mu \mathrm{g} / \mathrm{g}$ (40 ppm); aktivitas antioksidan tertinggi $44,56 \%$ dan memenuhi seluruh standar SNI 3836:2013 (kadar air, abu, serat kasar, ALT dan AKK).

Tabel 6. Total fenolik teh rambut jagung

\begin{tabular}{cccc}
\hline \hline Perlakuan & \multicolumn{2}{c}{ TPC $(\boldsymbol{\mu g} / \mathbf{g})$} & \\
\cline { 1 - 3 } Lama pelayuan & \multicolumn{2}{c}{ Usia panen } & $\overline{\mathbf{x}}$ \\
\cline { 2 - 3 } & Muda & Tua & $19,14^{\mathrm{A}}$ \\
\hline 0 jam (kontrol) & $21,54^{\mathrm{e}}$ & $16,75^{\mathrm{b}}$ & $17,85^{\mathrm{B}}$ \\
9 jam & $19,83^{\mathrm{d}}$ & $15,87^{\mathrm{a}}$ & $16,64^{\mathrm{C}}$ \\
\hline$\overline{\mathbf{x}}$ jam & $17,79^{\mathrm{c}}$ & $15,50^{\mathrm{a}}$ & $16,04^{\mathrm{Y}}$ \\
\hline \hline
\end{tabular}

*Nilai yang diikuti huruf yang sama menunjukkan perbedaan yang tidak nyata $(\mathrm{P}>0,01)$

Tabel 7. Aktivitas antioksidan (inhibisi DPPH) teh rambut jagung

\begin{tabular}{cccc}
\hline \hline Perlakuan & \multicolumn{2}{c}{ DPPH (\%) } & \multirow{2}{*}{$\overline{\mathbf{x}}$} \\
\cline { 1 - 3 } Lama pelayuan & \multicolumn{2}{c}{ Usia panen } & \\
\cline { 2 - 4 } & Muda & Tua & $39,69^{\mathrm{A}}$ \\
\hline 0 jam (kontrol) & $38,18^{\mathrm{a}}$ & $41,20^{\mathrm{b}}$ & $41,47^{\mathrm{A}}$ \\
9 jam & $44,56^{\mathrm{c}}$ & $38,38^{\mathrm{a}}$ & $39,61^{\mathrm{B}}$ \\
\hline 18 jam & $42,47^{\mathrm{b}}$ & $36,76^{\mathrm{a}}$ & \\
\hline$\overline{\mathbf{x}}$ & $41,73^{\mathrm{X}}$ & $38,78^{\mathrm{Y}}$ & \\
\hline \hline
\end{tabular}

*Nilai yang diikuti huruf yang sama menunjukkan perbedaan yang tidak nyata $(\mathrm{P}>0,01)$

\section{Simpulan dan Saran}

\section{Simpulan}

Usia panen memengaruhi kandungan antioksidan produk teh rambut jagung. Semakin tua usia panennya, maka semakin rendah kandungan dan aktivitas antioksidannya. Waktu pelayuan yang paling tepat untuk menghasilkan teh celup rambut jagung dengan kualitas fisik, organoleptik dan kandungan serta aktivitas antioksidan yang baik adalah 9 jam. Semua produk teh rambut jagung sesuai dengan SNI 3836:2013, sehingga layak untuk dikonsumsi dan dikembangkan lebih lanjut.

\section{Saran}

Sebaiknya digunakan bahan baku rambut jagung usia sedang untuk melihat aktivitas antioksidannya setelah diolah menjadi teh. Selain itu, perlu dilakukan penelitian in vivo untuk mengetahui keefektifan rambut jagung menurunkan kadar gula darah. Variasi perlakuan lain juga diperlukan, seperti variasi waktu fermentasi rambut jagung dan masa simpan.

\section{Ucapan Terima Kasih}

Ucapan terima kasih ditujukan kepada Fakultas Teknobiologi Universitas Atma Jaya Yogyakarta atas sarana prasarana yang disediakan selama penelitian berlangsung dan kepada staff Dinas Pertanian Yogyakarta atas bantuannya dalam pencarian bahan baku.

\section{Daftar Pustaka}

Aires, A. dan Carvalho, R. 2016. Compositional study and antioxidant potential of polyphenol extracted from corn by-product, using ultrasound extraction method. Austin Chromatography, 3 (1): $1-5$.

Apriady, R.A. 2010. Identifikasi senyawa asam fenolat pada sayuran indigenous Indonesia. Naskah Skripsi S-1. Fakultas Teknologi Pertanian Institut Pertanian Bogor, Bogor. 
Arifin, S. 1994. Petunjuk Teknis Pengolahan Teh dan Kina. Pusat Penelitian Teh dan Kina. Gambung, Bandung.

Azam, M., Jiang, Q., Zhang, B., Xu, C. dan Chen, K. 2013. Citrus leaf volatiles as affected by developmental stage and genetic type. International Journal of Molecular Sciences, 14: $17744-17766$

Badan Standardisasi Nasional. 1992. SNI 01-2891-1992 (Cara Uji Makanan dan Minuman). sisni.bsn.go.id. Diakses pada 24 Mei 2017.

Badan Standardisasi Nasional. 2013. SNI 3836:2013. (SNI teh kering dalam kemasan). sisni.bsn.go.id Diakses 24 Mei 2017.

Balittri, W.H. 2012. Potensi pengembangan teh se chi chuen sebagai bahan baku teh oolong. Warta Penelitian dan Pengembangan Tanaman Industri, 18 (3): 21-24.

Barku, V.Y.A., Opaku-Boahen, E., Owusu-Ansah dan Mensah, E.F. 2013. Antixodidant activity and the estimation of total phenolic and flavonoid contents of the root extract of Amaramthus spinosus. Asian Journal of Plant Science and Research, 3 (1): 69-74.

Carbrera, S.G., Perez, I.F.R., Aguilar, L.J.L., Caringal, M.C., Dado, A.G. dan Evangelista, D.M. 2015. Determination of properties of selected fresh and processed medicinal plants. Asia Pacific Journal of Multidisciplinary Research, 3 (4): 34-40.

deMan, J.M. 1977. Kimia Makanan. Edisi Kedua. ITB Press, Bandung.

deMan, J.M. 1999. Principles of Food Chemistry. Aspen Publishers Inc., New York.

Dewi, J.K. 2016. Kualitas teh celup dengan kombinasi teh oolong dan daun stevia (Stevia rebaudiana Bert). Naskah Skripsi S-1. Fakultas Teknobiologi Universitas Atma Jaya Yogyakarta, Yogyakarta.

El-Ghorab, A., El-Massry, K.F. dan Shibamoto, T. 2007. Chemical composition of the volatile extract and antioxidant activities of the volatile and nonvolatile extract of Egyptian corn silk (Zea mays L.). J. Agric Food Chem., 55: 9124-9127.

Fardiaz, S. 1992. Mikrobiologi Pangan. Gramedia Pustaka Utama, Jakarta.

Fardiaz, S. dan Margiono. 1993. Analisis Mikrobiologi Pangan. PT Raja Grafino Persada, Jakarta.

Gasperz, V. 1991. Metode Perancangan Percobaan. Amico, Bandung.

Handayani, Y. 2010. Kajian pembuatan teh celup dengan daun pegagan (Centella asiatica L. Urban). Naskah Skripsi S-1. Fakultas Teknologi Pertanian Institut Pertanian, Bogor.
Hartiko, H. 1983. Leaf and root in vivo nitrate reductase activities of coconut (Cocos nucifera L.) cultivars and hybrids. Disertation. Faculty of the Graduate School University of The Philippines at Los Banos, Philippines.

Harun, N., Rossi, E. dan Adawiyah, M. 2011. Karakteristik teh herbal rambut jagung (Zea mays) dengan perlakuan lama pelayuan dan lama pengeringan. Jurnal Sagu, 10 (2): 16-21.

Hidayat, N., Padaga M.C. dan Suhartini, S. 2006. Mikrobiologi Industri. Penerbit Andi, Yogyakarta.

Huang, H., Faulkner, D.B., Berger, D.L. dan Eckhoff, S.R. 2012. Harvest date influence on dry matter yield and moisture of corn and stover. Faculty Papers and Publications in Animal Science, 55 (2): 593-598.

Kustamiyati, S. 2006. Prospek Teh Indonesia sebagai Minuman Fungsional. lppi.go.id. Diakses 25 Mei 2017.

Lee, C. 2007. Corn Growth and Development. uky.edu. Diakses 22 Maret 2018.

Liu, J., Wang, C.N., Wang, Z.Z., Zhang, C., Lu, S. dan Liu, J.B. 2011. The antioxidant and free-radical scavenging activities of extract and fractions from corn silk (Zea mays L.) and related flavone glycosides. Food Chem, 126: 261-269.

McWilliams, D.A., Berglund, D.R. dan. Endres, G.J. 1999. Corn Growth and Management Quick Guide. ag.ndsu.edu. Diakses 22 Maret 2018.

Muchtadi, T.R. 1989. Teknologi Proses Pengolahan Pangan. Departemen Pendidikan dan Kebudayaan, Direktorat Jendral Pendidikan Tinggi, Pusat Antar Universitas Pangan dan Gizi, Institut Pertanian Bogor, Bogor.

Murdijati, G. dan Yuliana, R.S. 2014. Fisiologi Pascapanen Buah dan Sayur. Gadjah Mada University Press, Yogyakarta.

Orak, H.H. 2006. Total antioxidant activities, phenolics, anthocyanins, polyphenoloxidase activities and its correlation of some important red wine grapes varieties which are grown in Turkey. Electronic Journal of Polish Agricultural University Food Science and Technology, 9 (1): 18.

Pertamawati. 2010. Pengaruh fotosintesis terhadap pertumbuhan tanaman kentang (Solanum tuberosum L.) dalam lingkungan fotoautotrof secara in vitro. Jurnal Sains dan Teknologi Indonesia, 12 (1): 31-37.

Prihmantoro, H. dan Indriani, Y.H. 2000. Hidroponik Sayuran Semusim. Penebar Swadaya, Jakarta. 


\section{Hartanto dkk.,}

Putri, F.K. 2016. Aktivitas antioksidan dan kualitas teh kombinasi rambut jagung dan daun kelor dengan variasi suhu pengeringan. Naskah Skripsi S-1. Fakultas Keguruan dan Ilmu Pendidikan Universitas Muhammadiyah, Surakarta.

Rafiqah, N. 2011. Proses Fermentasi Tauco. repository.usu.ac.id. Diakses 16 Maret 2016.

Rohmatussolihat. 2009. Antioksidan: penyelamat sel-sel tubuh manusia. Bio Trends, 4 (1): 5-9.

Santosh, K.K. 2005. Nutritional evaluation and utilization of baby corn for product development. Thesis. Faculty of Food and Nutrition Chaudhary Charan Singh Haryana Agricultural University, New Delhi.

Santoso, Purwoko, B.B. dan Budi, S. 2012. Fisiologi dan Teknologi Pascapanen Tanaman Hortikultura. Universitas Mataram, Mataram.

Sarepoua, E., Tangwongchai, R., Suriharn, B. dan Lertrat, K. 2015. Influence of variety and harvest maturity on phytochemical content in corn silk. Food Chemistry, 169: 424-429.

Sembiring, N.V.N. 2009. Pengaruh kadar air dari bubuk teh fermentasi terhadap kapasitas produksi pada stasiun pengeringan teh PTPN IV unit kebuh Bah Butong. Karya Ilmiah. Universitas Sumatera Utara, Medan.
Siegbahn, P.E.M 2004. The catalytic cycle of catechol oxidase. Journal of Biological Inorganic Chemistry, 12: 1251-126.

Sudarmadji, S., Haryono, B. dan Suhardi. 2003. Prosedur Analisis Bahan Makanan dan Pertanian. Penerbit Liberty, Yogyakarta.

Sukalovic, V.H., Veljovic-Jovanovic, S., Maksimovic, J. D., Maksimovic, V. dan Pajic, Z. 2009. Characterisation of phenol oxidase and peroxidase from maize silk. Plant Biologi, 12 (3): 406-413.

Taranto, F., Pasqualone, A., Mangini, G. dan Montemurro, C. 2017. Polyphenol oxidases in crops: biochemical, physiological and genetic aspects. International Journal of Molecular Science, 18 (2): 1-16.

Venkatesan, S. dan Sujitha, S.D.A. Influence of genotype and manufacturing process on the activity of BD-Glucosidase and B-Galactosidase in tea American Journal of Plant Physiology, 2 (2): 175-182. 